\title{
POLITICAL REFORM OF LABOR PROTECTION LAW IN THE GLOBALIZATION ERA
}

\author{
Arpangi \\ Sultan Agung Islamic University \\ arpangi@unissula.ac.id
}

\begin{abstract}
In its development, economic globalization has created an affiliation between the local economy and the international economy. It resulted in an extraordinary blow to the economic system in third world countries that were trying to become developed countries. It can be seen in the issue of protecting workers' welfare, which is not fair. So, this article intends to discuss related to the protection of workers' welfare in the era of globalization and the weaknesses that affect the protection of labor rights in the era of globalization, which can't realize justice for workers. The article is expected to be able to stimulate each party to re-discuss the issue of protecting labor welfare in the current era of globalization in Indonesia.the results of research produced are The factors that influence injustice in protecting workers' welfare in Indonesia are Legal rule factors, Influence Factors of Globalization can also be concluded that the failure of labor law politics in Indonesia will have an impact on the increasing poverty rate in Indonesia due to increasing unemployment in Indonesia as one of the effects of the flood of foreign workers in Indonesia with the number of employment that is running low.
\end{abstract}

Keywords: Globalization, Labor Protection, Political Reform.

\section{A. INTRODUCTION}

Global developments are encouraging the increasing mobility of the world's population which has various impacts, both beneficial and detrimental to the interests and lives of the nation and state of the Republic of Indonesia. In the implementation of national development, manpower has a very important role and position as an agent and development goal. In consideration of Act No. 13 of 2003 concerning Manpower states that protection of labor is intended to guarantee the basic rights of workers/laborers and guarantee equal opportunities and treatment without discrimination on any grounds to realize the welfare of workers/laborers and their families while taking into account developments in the progress of the business world. In subsequent developments, the rise of Foreign Workers especially those coming from China who entered Indonesia caused problems related to their activities while in Indonesian territory. ${ }^{1}$

1 Ahmad Jazuli, The Existence of Foreign Workers in Indonesia From The Immigration Law Perspective, JIKH, Vol. 12 No.1 Maret 2018, P.89-105 
Industrial relation is a means to achieve harmony between employers, employees, and the government to achieve calm in the business world or the industrial world. Industrial relations in Act No. 13 of 2003 paragraph (1) No. 16 is stated as a system of relationships formed between actors in the process of producing goods and/or services consisting of elements of employers, workers or laborers and the government based on the values contained in Pancasila and the 1945 Constitution of the Republic of Indonesia.

Industrial relations is basically significant in the industrial world because industrial development is a means of realizing harmony between employers and workers so that the implementation of the business world will be able to run well as mandated by the Pancasila and the Constitution of the Indonesian state, which then leads to the achievement of economic growth and the welfare of the nation. The development of economic growth in a country is in line with the population growth and the fundamental development of the existing economic structure. ${ }^{2}$

Economic development can affect the system of economic growth in society or often refer to economic growth, in other words, economic development will be able to support the success of economic development, and economic development also can facilitate the achievement of economic development in society. Development and economic growth in the community itself are influenced by factors in the form of Natural Resources, Human Resources, and Expertise, and Entrepreneurship. ${ }^{3}$

While Human Resources, namely labor, which is seen both in terms of quality and quantity, and the Expertise and Entrepreneurship in question is the ability of each Human Resource to be able to increase the economic value of goods through the process of production, distribution, and trade. From the explanation of the important factors in conducting the above business, it can be concluded that another factor which is also important is the effort to create a conducive industrial development.

The development of a conducive industry requires the synchronization of three layers, namely the layers of employers, workers, and government. These layers are also referred to as aspects of Human Resources incorporated in the industrial development system. Synchronization in the field of Human Resources in the industrial development system is intended so that investment can develop properly. It is because the investment will improve if the industrial world in the country can run safely for investors both from outside and within the state. It is achieved the need for a conducive industrial development so that investment will develop and economic growth is achieved. ${ }^{4}$

However, the harmonization of work relations between employers and employees is not easy in the era of globalization. The mainstream of economic

2 Bambang Supriyanto, Peranan Organisasi Pekerja/Organisasi Buruh Dan Organisasi Pengusaha Dalam Penciptaan Iklim Berusaha Yang Kondusif, Industrial Relation Forum, Yogyakarta, 2009, p. 2

3 Ibid, p. 2

4 Bambang Supriyanto, Peran Organisasi Pekerja/Buruh Dan Orgnisasi Pengusaha Di Dalam Penciptaan IKlim Berusaha Yang Kondusif, Indonesian Ministry of Manpower and Transmigration, Yogyakarta, 2009, p. 10 
globalization in the business world has made business competition uncontrollable. It has resulted in the turbulence of increasingly pragmatic business objectives, which is not infrequently sacrifice not only employers but also labor rights. It is supported by data stating that there were 208 cases of layoffs, which resulted in 1,377 people losing their jobs, and the most number was in the DKI Jakarta area, which was 1,047 people.5 This data shows that layoffs have always been a problem that is constantly being experienced by workers unjustly, which until now workers have also been unable to do much about the problem.

It is further complicated by the presence of foreign workers in Indonesia today. In its development, the Indonesian state in the era of the ASEAN Economic Community or MEA is currently being invaded by foreign workers. Foreign workers, according to Presidential Regulation No. 20 of 2018 Concerning Foreign Workers, are foreign nationals holding a visa who intend to work in Indonesia. This shows that every foreign citizen holding a visa can easily enter to become a foreign worker. In its development, the arrival of foreign workers also gives advantages to the countries of the foreign workers, one of which is to reduce unemployment.

Based on various kinds of existing problems, it is necessary to have a discussion related to "Political Reform of Labor Protection Law in the Globalization Era."

\section{B. RESEARCH METHODS}

The type of approach in this writing is sociological juridical, which is a legal approach that sees legal issues not only in normative legal issues but also in sociological and philosophical issues in law. The specifications of this study indicate a descriptive study, which is a study conducted by describing the facts that exist or the activities carried out by the object under study. Descriptive research is one type of research whose aim is to present a complete picture of a social reality phenomenon, clearly describing a number of variables with the problem under study. ${ }^{6}$

\section{DISCUSSION}

\section{Protection of Labor Welfare in the Era of Globalization}

The purpose of Republic of Indonesia in paragraph IV of the Preamble to the 1945 Constitution of Republic of Indonesia in its development has yet to be realized. The goal of the country has not been realized due to the threat of globalization that has been and is ongoing. According to Mansour Fakih, globalization is "the process of integrating the

5 Tempo.co Edition 11 February 2019, Data Jumlah PHK Menurut Kementerian Tenaga Kerja, Retrieved on 21 April 2020.

6 Muhammad Yusuf, Andri Winjaya Laksana, Upaya Kejaksaan Dalam Pembuktian Tindak Pidana Pengeroyokan Dalam Persidangan Pidana (Studi Kasus Kejaksaan Negeri Demak), Prosiding Konferensi IImiah Mahasiswa Unissula (KIMU) 2 Universitas Islam Sultan Agung Semarang, 18 Oktober 2019, P.248-262. 
national economy into the world economic system with the free market belief that had been declared during colonialism."

The commencement of the globalization process was simply marked by the enactment of a free trade mechanism globally with the approval of a trade agreement known as the General Agreement on Tariffs and Trade (GATT) in the eighth round known as the Uruguay Round (GATT-UR). The Uruguay Round negotiations themselves took place from 1986 until it was agreed to in 1994 through the signing of the Final Act Embodying the Results of the Uruguay Round of Multilateral Trade Negotiations along with the WTO Agreement and its attachments in Marrakech 15 April 1994 by 124 member countries. ${ }^{8}$ The goal is clear, namely to get rid of all forms of state protection for the institutionalization of the world free market. Developed countries argue, with the free trade-free competition without state protection, the market mechanism will work self-regulating (or selfcorrecting) through the invisible hand to create economic efficiency and prosperity. ${ }^{9}$ In the propaganda of developed countries, globalization through free trade is nothing but promised as a process of the world economy to realize the welfare of humanity in the world. However, in reality, the world free-market economic system created by developed countries is nothing but the interests of developed countries to regain control of the world economy as they did in the era of colonialism.

In connection with the issue of legal protection for migrant workers which is interstate, it is necessary to have an agreement between the State of Indonesia and the country where the migrant worker is located. The agreement is called an international agreement, that is, an agreement in the form and name specified in international law which is made in writing and gives rise to rights and obligations in the field of public law. Because the international agreement concerns the interests of the two countries, the contents of the agreement must be able to harmonize the authority the two States are for mutual interests and goals without reducing the jurisdiction of their respective States. The position of the international treaty is in the middle between the two countries concerned, so it does not take sides or burden any of the countries. Because it concerns the relations between the two countries, what the Indonesian government can do is improve diplomatic relations between the two countries. As stipulated in Law No.37 of 1999 Article 7 letter D, which states that the government is making diplomatic efforts to ensure the fulfillment of the rights and protection of migrant workers. optimally in the destination country. ${ }^{10}$

As a means of driving the globalization of the IMF and the World Bank is tasked with providing financial assistance to third world countries

7 Mansour Fakih, Sesat PikirTeori Pembangunan Dan Globalisasi, Pustaka Pelajar, Yogyakarta, 2001, P. 210.

8 Achmad Zen Umar Purba, Perjanjian TRIPs dan Beberapa Isu Strategis, 1st edition, Badan Penerbit FH UI dan PT. Alumni, Jakarta-Bandung, 2011, P. 6.

9 Mansour Fakih, Op.Cit, P.216.

10 Arpangi, Pelindungan Hukum Terhadap Tenaga Kerja Indonesia Di Luar Negeri, Jurnal Pembaharuan Hukum, Vol.III No. 1 Januari - April 2016, P.149-156. 
that are hit by the economic crisis. The financial assistance program requires third world countries to make adjustments to their national policies for the smooth process of integrating the national economy into the world economy (Globalization). The policy recommendations are known as the Washington Consensus, which among others recommend: (1) Liberalization of trade or free trade; (2) Capital market liberalization; (3) Floating exchange rates; (4) Interest rates are determined by the market; (5) Market deregulation; (6) Privatization of State-Owned Enterprises (BUMN); (7) Diverting subsidies to the public or social sector; (8) Disciplined fiscal budget or balanced budget; (9) Tax reform; (10) Protection of Intellectual Property Rights. According to the IMF and the World Bank, by implementing all of the policy recommendations, a healthy and debt-free government will be created and will bring prosperity to these countries.

However, in reality, the process of globalization causes the widening gap between developed and developing countries. A data reveals that in the late 1990s, which was the first decade of globalization, $20 \%$ of the world population enjoyed $86 \%$ of world income. The intended population is the population living in developed countries. This is inversely proportional to the fact that the $20 \%$ of the bottom population, who mostly live in third world countries, only get $1 \%$ of world income. The data also reveal that in 1960 , as many as $20 \%$ of the top population earned 30 times more than the bottom $20 \%$ of the population. The ratio was 32 times greater in 1970, 45 times in 1980, 60 times in 1990, and 75 times in the late 1990s. In the late 1990s, it was also revealed that 80 developing countries had smaller per capita incomes than in the late 1980s.

Based on Chomsky's thought above, AmienRais concluded that globalization caused corporate crimes that tended to violate human rights, damage the environment, and deplete the natural wealth of third world countries that were difficult to reach by law and politics. This causes the economy of developed countries to get stronger and weaken third world countries because there has been a world economic gap. Furthermore, James K. Galbraith argues that the created socioeconomic gap is a perfect crime.

Various intrusions of the impact of economic globalization on its development resulted in various problems in all aspects of the life of the people of third world countries, in this case, including the Indonesian state. The various issues that were present as result of the emerging of neocolonialism through the means of globalization also included labor issues. Basically, labor is the frontline in bringing stability and economic progress in the country of Indonesia. Development and economic growth in the community itself is influenced by factors in the form of Natural Resources, Human Resources, and Expertise, and Entrepreneurship. The explanation above clearly shows that there is a correlation between globalization, changes in the economic system, and changes in the welfare system of workers, which is increasingly changing the capitalist economic situation inversely with the improvement of workers' health. This is because the 
intrusion of the interests of globalization agents also to dominate third world countries, especially the mastery of human capital.

\section{Issues that Exist in the Implementation of Labor Welfare Protection in the Globalization Era}

a. Legal Regulatory Factors

Foreign workers, according to Presidential Regulation No. 20 of 2018 Concerning Foreign Workers, are foreign nationals holding a visa who intend to work in Indonesia. This shows that every foreign citizen holding a visa can quickly enter to become a foreign worker. In its development, the arrival of foreign workers also gave clappings to the countries of origin of foreign workers, one of which was to reduce unemployment.

Regulations on foreign workers are contained in chapters VIII articles 42 to 49. In Act number 13 of 2003 concerning Ketenagakerjaan that employers who will use foreign workers must have a use plan that includes reasons, position to be occupied, period of time, and there must be someone who accompanies Indonesian workers. The plan to use foreign workers must be approved by the Minister, and as a requirement for obtaining a work permit. Foreign workers must have competency standards and qualifications of knowledge, expertise, skills in certain fields, and understanding of Indonesian culture. Assistance to foreign workers focuses on technology transfer and transfer of expertise so that the accompanying workforce can have the ability so that in time it is expected to be able to replace the foreign workers they assist. Foreign workers are prohibited from occupying personnel and certain positions that are regulated by a Ministerial Decree. after the employment relationship ends, the employer is required to repatriate foreign workers to their country of origin. ${ }^{11}$

Philosophical use of foreign workers, namely the principle of benefits, security aspects, legal aspects, namely the entry of foreign workers must obtain a work permit from the Minister of Manpower, related to the use of foreign workers is to meet the needs of professional workers in certain fields that can be used by migrant workers with the acceleration of technology experts and increased investment. Using foreign workers in Indonesia cannot be used, and in principle the use of foreign workers in Indonesia are those who are needed in two ways, they are foreign workers who bring capital (as investors) and bring skills in terms of knowledge transfer. ${ }^{12}$

So it is clear that the increase in the number of Foreign Workers in Indonesia is also supported by the Presidential Regulation No. 20 of 2018. The regulation provides flexibility for Chinese investors to use and bring in workers from their country in large numbers. This case can be

11 Nurhidayati, Perizinan Tenaga Kerja Asing, Kebijakan dan Implementasinya, Widya Cipta: Jurnal Sekretari dan Manajemen, Vol. 3 No. 2 September 2019, P.241-248

12 Meiliana Wanda Agesa, Lego Karjoko, Isharyanto, Politik Hukum Fasilitas Keimigrasian Bagi Tenaga Kerja Asing Dengan Hukum Ketenagakerjaan Indonesia, Jurnal Hukum Dan Pembangunan Ekonomi, Vol 6 No.2 P.55-72 
seen by the provisions of Article 3 letter c Presidential Regulation No. 20 of 2018, which states that the parties that can bring inforeign workers are foreign private companies that are doing business in Indonesia. Besides, the article also provides a loophole for foreign workers not only from China to come to Indonesia through work calls from institutions, as stated in Article 3 of Presidential Regulation No. 20 of 2018. Meanwhile, Act No. 13 of 2003 has not regulated in full related to foreign workers. Besides, there is disharmony between Perpres No. 20 of 2018 and Act No. 13 Of 2003. This can be seen in the provisions of Article 9 of PerpresNo. 20 of 2018, which states that the ratification of the Plan for the Use of Foreign Workers (RPTKA) is a requirement for obtaining a work permit.

It is different from the provisions of Article 43 of Law No. 13 of 2003, which not only makes RPTKA the only entry offoreign workerinto the Indonesian state. However, foreign worker must also have a permit in the form of aforeign workerpermit. Besides, Article 9 of Presidential Regulation No. 20 of 2018 also contradicts Article 8 of Presidential Regulation No. 72 of 2014 concerning Foreign Workers, which states that Foreign Workers can work in Indonesia on the condition of having a RPTKA and Permit to Employ Foreign Workers from Employers who employ Foreign Workers. The disharmony of Article 9 of Presidential Regulation No. 20 of 2018 with various provisions of labor law in Indonesia shows that the making of Presidential Regulation No. 20 of 2018 does not go through a thorough academic study. It is clearly seen that the politics of labor law currently still has many weaknesses in terms of the regulation of foreign workers, which will eventually be able to cause employment problems and the problem of employing indigenous people of Indonesia who need livelihoods and the viability of economic life in the country. This clearly contradicts the Five Principles of Pancasila and Article 27 No. 2 of the 1945 Constitution of the Republic of Indonesia relating to the right to have decent work and livelihood for Indonesian citizens.

b. Economic Globalization Factors

Economic structure change from the agricultural sector to the industrial sector have long been regarded as one of the factors causing the entry of foreign workers into a country's labor market. This change in economic structure has led to the emergence of dualism in the labor market, namely the primary labor market (particularly in the industrial sector) which is characterized by generally stable work characteristics, high wages, pleasant work atmosphere, and provides many conveniences. While the secondary labor market, for example in the agricultural sector, has the opposite characteristics, namely erratic employment, low wages, unpleasant working atmosphere, and full employment with risks. The interesting hypothesis put forward regarding this foreign workers is that the higher the economic development achieved by a country, the more job opportunities available to foreign workers. Changes in the economic structure that lead to a better working 
atmosphere cause local workers to be more interested in working in the primary labor market, while jobs that are not filled in the secondary labor market are opportunities for foreign workers to enjoy them. Therefore, the change in the structure of the economy from the agricultural sector to the industrial sector is often regarded as one of the important factors influencing the entry of foreign workers into a country's labor market. ${ }^{13}$

Basically, the sad condition of Indonesian workers is due to the emergence of tyrannical developed countries' agendas through tempting economic globalization. Noam Chomsky's explanation above seems to have taken place through the extension of the agents of globalization, namely the World Trade Organization or abbreviated as WTO. This is shown by the existence of historical facts which explain that discussions related to labor in WTO meetings can be seen as a form of protection against the Multy National Corporation and Trans-National Corporation originating from developed countries that have power and influence in the United Nations. This can be seen from the existence of trading dumping practices in the free market, one of which is by lowering the wages of laborers to reduce the number of goods produced to gain the maximum profit in free trade.

In the era of globalization, foreign workers are free to enter Indonesia, due to the existence of the ASEAN Economic Community, whose implementation began in 2015. The implementation of the ASEAN Economic Community will place Indonesia as a major market for both the flow of goods and investment. From the aspect of employment there is a huge opportunity especially for job seekers because there will be jobs with a variety of diverse expertise needs. The presence of foreign workers is a real reality, and even plays an important role in supporting the functioning of the economic sector in Indonesia. ${ }^{14}$

In accordance with the cooperation in the economic sector regulated in the ASEAN Community, the goods, services and investment markets can move freely without geographical restrictions. Specifically for the workforce, the 2015 MEA will definitely have a direct impact on Indonesian employment.

Theoretically, liberalization in the markets for goods, services, capital and labor will increase labor productivity, because it will create conditions that encourage companies to allocate resources more efficiently. The unlimited mobility of the workforce will certainly make work opportunities for the workforce broader with broad area coverage. Workers can freely choose the type of work in accordance with what they want and the company can also choose employment in accordance with its specifications. However, this should not make the Indonesian people happy first because precisely when the goods and services market begins without the readiness of qualified human resources,

13 Nasri Bachtiar dan Rahmi Fahmi, PENGARUH TENAGA KERJA ASING TERHADAP PERTUMBUHAN EKONOMI DAN KESEMPATAN KERJA: Suatu Tinjauan Literatur, Jurnal Kependudukan Indonesia, Vol. VI, No. 1, 2011, P.63-85

14 Fitratunnisa, Dampak Tenaga Kerja Asing Terhadap Sosial Kemasyarakat Masyarakat Kota Dumai, JOM FISIP, Vol.4 No.1 Februari 2016, P.1-15 
we will only be the spectators of success in our own country. As is currently the case, a large number of Indonesian migrant workers tend to be dominated by low-skilled workers. AEC 2015 also requires Indonesian workers to have more than average expertise in order to compete with foreign workers from neighboring countries. Therefore, it is necessary to improve the quality of Indonesian workers. ${ }^{15}$

In the era of globalization, foreign workers are free to enter Indonesia, due to the presence of the ASEAN Economic Community, whose implementation began in 2015. The implementation of the ASEAN Economic Community will place Indonesia as a major market for both the flow of goods and investment. From the aspect of employment there is a huge opportunity especially for job seekers because there will be jobs with a variety of diverse expertise needs. The presence of foreign workers is a real reality, and even plays an important role in supporting the functioning of the economic sector in Indonesia

The factor of globalization has indirectly forced and encouraged the movement of labor between countries. The use of foreign workers cannot be avoided, in this era of globalization in Indonesia. Indeed, the use of Foreign Workers in Indonesia are those who are needed in 2 (two) ways, they are (Foreign Workers) who bring capital (as investors) and/or bring skills in terms of transfer of knowledge or transfer of know how. Apart from these two things, in essence, it is not permitted and must prioritize the use of labor from Indonesia. ${ }^{16}$

With the increasing number of foreign workers in Indonesia, the most important aspect to consider is the legal protection of workers. Legal protection for workers is the fulfillment of basic rights inherent and protected in the constitution, as stipulated in Article 27 paragraph (2) of the 1945 Constitution which states "Every citizen has the right to work and a decent living for humanity". It is stated that every citizen means that this is no exception for Indonesian citizens and foreign citizens must have legal certainty in it which gives a sense of justice. ${ }^{17}$

China, which increased its investment value in Indonesia by USSD 2,665 million in its development, also sent its workforce to Indonesia by 21,300 people. The entry of foreign workers from China has resulted in a significant increase in unemployment in this country. The data from the Institute for Development of Economics and Finance, which states that the unemployment rate in 2019 would increase to $53 \%$. So, it can also be concluded that the failure of labor law politics in Indonesia will have an impact on increasing poverty rates in Indonesia due to rising unemployment in Indonesia. It's caused by increasing foreign workers in Indonesia, resulting in a low number of employments.

15 Erliz Nindi Pratiwi, Rifa Atun Mahmudah, Peningkatan Daya Saing Tenaga Kerja Indonesia Melalui Korelasi Input Penunjang Tenaga Kerja Dalam Menghadapi MEA 2015, Economics Development Analysis Journal, Vol.2 No.2 2013, P.1-7

16 Moch Thariq Shadiqin, Perlindungan Hukum Terhadap Tenaga Kerja Asing Berdasarkan Asas Kepastian dan Keadilan, Administrative Law \& Governance Journal. Vol.2 Issue 3, August 2019, P.558-570.

17 Ibid. 


\section{Conclusion}

The factors that influence injustice in protecting workers' welfare in Indonesia are: Legal rule factors Presidential Regulation No. 20 Of 2018. The Perpres gives Chinese investors the freedom to use and bring in large numbers of workers from their country of origin. Influence Factors of Globalization : The State of Indonesia in the era of the ASEAN Economic Community or MEA is currently being invaded by foreign workers in the job market. This is shown by the attitude of the Chinese state, which increased the value of its investment in Indonesia by USSD 2,665 million, which in its development also asked Indonesia to accept its workforce to Indonesia by 21,300 inhabitants.

\section{BIBLIOGRAPHY}

Achmad Zen Umar Purba, 2011, Perjanjian TRIPs dan Beberapa Isu Strategis, $1^{\text {st }}$ edition, Badan Penerbit FH UI dan PT. Alumni, JakartaBandung;

Ahmad Jazuli, The Existence of Foreign Workers in Indonesia From The Immigration Law Perspective, JIKH, Vol. 12 No.1 Maret 2018;

Arpangi, Pelindungan Hukum Terhadap Tenaga Kerja Indonesia Di Luar Negeri, Jurnal Pembaharuan Hukum, Vol.III No. 1 Januari-April 2016;

Bambang Supriyanto, 2009, Peranan Organisasi Pekerja/Organisasi Buruh Dan Organisasi Pengusaha Dalam Penciptaan Iklim Berusaha Yang Kondusif, Industrial Relation Forum, Yogyakarta;

Erliz Nindi Pratiwi, Rifa Atun Mahmudah, Peningkatan Daya Saing Tenaga Kerja Indonesia Melalui Korelasi Input Penunjang Tenaga Kerja Dalam Menghadapi MEA 2015, Economics Development Analysis Journal, Vol.2 No.2 2013;

Fitratunnisa, Dampak Tenaga Kerja Asing Terhadap Sosial Kemasyarakat Masyarakat Kota Dumai, JOM FISIP, Vol.4 No.1 Februari 2016;

Mansour Fakih, 2001, Sesat Pikir Teori Pembangunan Dan Globalisasi, Pustaka Pelajar, Yogyakarta;

Meiliana Wanda Agesa, Lego Karjoko, Isharyanto, Politik Hukum Fasilitas Keimigrasian Bagi Tenaga Kerja Asing Dengan Hukum Ketenagakerjaan Indonesia, Jurnal Hukum Dan Pembangunan Ekonomi, Vol 6 No.2;

Moch Thariq Shadiqin, Perlindungan Hukum Terhadap Tenaga Kerja Asing Berdasarkan Asas Kepastian dan Keadilan, Administrative Law \& Governance Journal. Vol.2 Issue 3, August 2019;

Muhammad Yusuf, Andri Winjaya Laksana, Upaya Kejaksaan Dalam Pembuktian Tindak Pidana Pengeroyokan Dalam Persidangan Pidana (Studi Kasus Kejaksaan Negeri Demak), Prosiding Konferensi IImiah Mahasiswa Unissula (KIMU) 2 Universitas Islam Sultan Agung Semarang, 18 Oktober 2019; 
Nasri Bachtiar dan Rahmi Fahmi, PENGARUH TENAGA KERJA ASING TERHADAP PERTUMBUHAN EKONOMI DAN KESEMPATAN KERJA: Suatu Tinjauan Literatur, Jurnal Kependudukan Indonesia, Vol. VI, No. 1, 2011;

Nurhidayati, Perizinan Tenaga Kerja Asing, Kebijakan dan Implementasinya, Widya Cipta: Jurnal Sekretari dan Manajemen, Vol. 3 No. 2 September 2019;

Tempo.co Edition 11 February 2019, Data Jumlah PHK Menurut Kementerian Tenaga Kerja, Retrieved on 21 April 2020; 